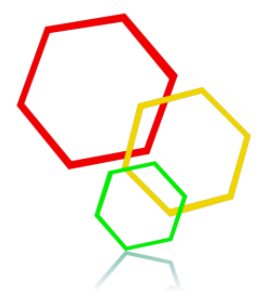

Вісник Дніпропетровського університету. Серія Хімія Bulletin of Dnipropetrovsk University. Series Chemistry

p-ISSN 2306-871X, e-ISSN 2313-4984

journal homepage: http://chemistry.dnu.dp.ua

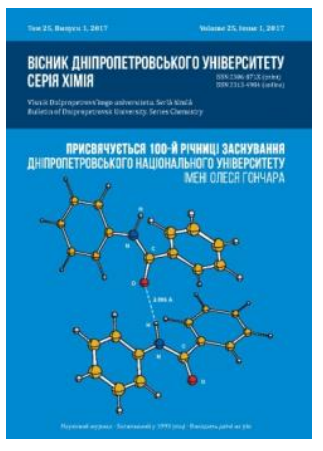

UDC 544.653.2

\title{
THE ELECTROCHEMICAL OXIDATION OF SALICYLIC ACID AND ITS DERIVATIVES ON MODIFIED PbO 2 -ELECTRODES
}

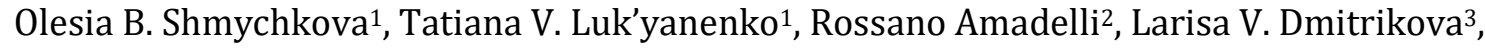 \\ Alexander B. Velichenko ${ }^{*}$ \\ 1 Ukrainian State University of Chemical Technology, 8, Gagarin Ave., 49005 Dnipro, Ukraine \\ 2ISOF-CNR u.o.s Ferrara c/o Department of Chemical and Pharmaceutical Sciences, University of Ferrara, \\ Via Luigi Borsari, 46-44121 Ferrara, Italy \\ 3 Oles Honchar Dnipropetrovsk National University, 72, Gagarin Ave., 49050 Dnipro, Ukraine \\ Received 30 March 2017; revised 05 May 2017; accepted 26 June 2017, available online 05 December 2017
}

\section{Abstract}

The results of the study of electrochemical oxidation of salicylic acid on $\mathrm{PbO}_{2}$-based anodes for effective wastewater treatment from organic pollutants have been summarized. Both the influence of various factors on the decomposition rate of organic substances and the influence of various modifying additives of lead dioxide anode on the process of mineralization of salicylic acid have been established. The total probable sequence of reactions to salicylic acid mineralization has been proposed. It is established that the destruction of salicylic acid in the first stage occurs through the accumulation of aromatic hydroxylation products, and during the total destruction - the destruction of the aromatic system with the formation of aliphatic compounds takes place. It is shown that the use of $\mathrm{PbO}_{2}$, deposited from methanesulfonate electrolytes and modified electrodes significantly reduces the conversion time of salicylic acid in aliphatic products compared to lead dioxide anodes obtained by traditional technology from nitrate bath. The highest degradation rate occurs at the anodes modified by bismuth. It was found that the destruction of the 5-aminosalicylic acid occurs through an intermediate oxidation of amino-group to hydroxy.

Keywords: lead(IV) oxide, methanesulfonate electrolyte, electrochemical oxidation, salicylic acid.

\section{ЕЛЕКТРОХІМІЧНЕ ОКИСНЕННЯ САЛІЦИЛОВОЇ КИСЛОТИ ТА ЇЇ ПОХІДНИХ НА МОДИФІКОВАНИХ РЬО 2 -ЕЛЕКТРОДАХ}

Олеся Б. Шмичкова¹, Тетяна В. Лук'яненкоํ, Росано Амаделлі², Лариса В. Дмітрікова³, Олександр Б. Веліченко ${ }^{1 *}$

1 ДВНЗ «Український державний хіміко-технологічний університет», пр. Гагаріна 8, м. Дніпро, 49005 Украӥна 2ISOF-CNR відділення в Феррарі, департамент хімії та фармації, Університет Феррари, вул. Л. Борсарі, 46-44121 Феррара, Італія

зДніпропетровський національний університет імені Олеся Гончара, 72, пр. Гагаріна, Дніпро, 49050 Україна Анотація

У роботі наведено результати дослідження електрохімічного окиснення саліцилової кислоти на діоксидносвинцевих анодах з метою ефективного очищення стічної води від органічних забрудників. Встановлено вплив різних факторів на швидкість процесів деструкції органічних речовин. Виявлено вплив різноманітних модифікуючих домішок діоксидносвинцевого електроду на процес окиснення саліцилової кислоти. Запропонована ймовірна загальна послідовність реакцій для мінералізації саліцилової кислоти. Показано, що під час руйнування саліцилової кислоти на першому етапі відбувається накопичення ароматичних продуктів гідроксилювання, а під час повної деструкції - руйнування ароматичної системи з утворенням аліфатичних сполук. Виявлено, що за використання $\mathrm{PbO}_{2}$, осадженого з метансульфонатних розчинів, та $\mathrm{PbO}_{2}$, модифікованого добавками іонів, суттєво зменшується час конверсії саліцилової кислоти в аліфатичні продукти порівняно із часом за використання плюмбум(IV) оксиду, осадженого за традиційною технологією з нітратних розчинів. Найбільша швидкість перетворення спостерігається за використання діоксидно-свинцевого аноду, модифікованого Бісмутом. Було виявлено, що руйнування 5-аміносаліцилової кислоти проходить через проміжне окиснення аміно-групи до гідрокси-групи.

Ключові слова: плюмбум(IV) оксид, метансульфонатний електроліт, електрохімічне окиснення, саліцилова кислота.

*Corresponding author: Tel.: +380562473627; e-mail address: velichenko@ukr.net

(C) 2017 Oles Honchar Dnipropetrovsk National University

doi: 10.15421/081706 


\title{
ЭЛЕКТРОХИМИЧЕСКОЕ ОКИСЛЕНИЕ САЛИЦИЛОВОЙ КИСЛОТЫ И ЕЕ ПРОИЗВОДНЫХ НА МОДИФИЦИРОВАННЫХ РЬО2-ЭЛЕКТРОДАХ
}

\author{
Олеся Б. Шмычкова ${ }^{1}$, Татьяна В. Лукьяненко ${ }^{1}$, Россано Амаделли르, Лариса В. Дмитрикова ${ }^{3}$, \\ Александр Б. Величенко ${ }^{1, *}$ \\ 1ГВУЗ «Украинский государственных химико-технологический университет», пр Гагарина 8, г. Днипро, 49005, \\ Украина \\ 2ISOF-CNR отделение в Ферраре, департамент химии и фармации, Университет Феррары, \\ ул. Л. Борсари, 46-44121 Феррара, Италия \\ ${ }_{3}$ Днепропетровский национальный университет имени Олеся Гончара, 72, пр. Гагарина, Днипро, 49050 Украина
}

\begin{abstract}
Аннотация
В работе приведены результаты исследования электрохимического окисления салициловой кислоты на диоксидносвинцовых анодах с целью эффективной очистки сточной воды от органических загрязнителей. Установлено влияние различных факторов на скорость процессов деструкции органических веществ. Показано влияние различных модифицирующих добавок диоксидносвинцового электрода на процесс окисления салициловой кислоты. Предложена вероятная общая последовательность реакций для минерализации салициловой кислоты. Установлено, что при разрушении салициловой кислоты на первом этапе происходит накопление ароматических продуктов гидроксилирования, а при полной деструкции разрушение ароматической системы с образованием алифатических соединений. Показано, что при использовании $\mathrm{PbO}_{2}$, осажденного из метансульфонатных электролитов, а также модифицированного $\mathrm{PbO}_{2}$ существенно снижается время конверсии салициловой кислоты в алифатические продукты по сравнению со временем при использовании диоксидносвинцового анода, осажденного по традиционной технологии из нитратной ванны. Наибольшая скорость превращения наблюдается на диоксидносвинцовом аноде, модифицированном висмутом. Было установлено, что деструкция 5-аминосалициловой кислоты происходит через промежуточное окисление амино-группы до гидрокси-группы.
\end{abstract}

Ключевые слова: плюмбум(IV) оксид, метансульфонатный электролит, электрохимическое окисление, салициловая кислота.

\section{Introduction}

The development of new highly efficient methods to wastewater treatment is one of the most serious problems faced by researchers $[1 ; 2]$. Known purification methods have several disadvantages associated with significant energy consumption or imperfection of disinfection. Hence there is the need for new methods to rapidly and efficiently destruct organic pollutants to $\mathrm{CO}_{2}$ and $\mathrm{H}_{2} \mathrm{O}$.

The choice of optimal technological schemes of water purification are quite a challenge because of the large amount of impurities that are in it, and because of the high demands placed on the quality of treated water. However, it should be noted that the electrochemical water treatment methods are now increasingly spreading in practice due to their high efficiency and functionality. Apparatus for implementing these methods is quite compact, high-performance, management and operation processes can be relatively easily automated. In addition, electrotreatment for its proper combination with other methods can successfully purify natural and wastewater from a number of different additives and dispersion. Very positive is the fact that for the electrochemical treatment is usually not increased salinity of water and ruled out the formation of more toxic pollutants. This method provides in some cases not only clean but also disinfected water. This provides significant advantages of electrochemical methods to traditional methods of water treatment [3-10].

Careful study of the mechanism of anodic reactions might help in the future to increase the selectivity and the using of preparative electrochemical organic chemistry processes [11].

Salicylic acid is one of the most common pollutants of wastewater. The latter is used in many pharmaceutical and cosmetic preparations. It is known to get by hydrolytic deacetylation of acetylsalicylic acid (aspirin), which is a major source of accumulation in wastewater. Thousands of tons of pharmaceuticals consumed annually worldwide man used in veterinary medicine and in agriculture. Due to inefficient destruction of pollutants sewage plants, quite a number of these substances was found in soil and even water. This necessitates the development of powerful methods for oxidation to effectively remove drugs and their metabolites from wastewater [12].

Water purification of salicylic acid is possible through oxidative destruction. There are different ways of salicylic acid oxidation of which the electrochemical oxidation is considered the most promising [13-15]. It is proved that the efficiency of oxidation depends on the material of the anode. The use of oxides as electrode materials in most cases is advantageous compared to metal electrodes, this allows a lower cost electrode and ensures to control occurred electrochemical processes due to change of the composition of oxide during its synthesis. 
The aim of our work was to study the electrochemical destruction of salicylic acid and its derivatives on lead(IV) oxide-based anode materials.

\section{Experimental and Methods}

All chemicals were reagent grade. Platinized titanium was used as substrate. Titanium sheet was treated as described in [16] before platinum layer depositing. Lead dioxide coatings were electrodeposited at anodic current density $10 \mathrm{~mA} \cdot \mathrm{cm}^{-2}$ from nitrate / methanesulfonate electrolytes that contained $0.1 \mathrm{M} \quad \mathrm{HNO}_{3} / \mathrm{CH}_{3} \mathrm{SO}_{3} \mathrm{H}, \quad 0.1 \mathrm{M}$ $\mathrm{Pb}\left(\mathrm{NO}_{3}\right)_{2} / \mathrm{Pb}\left(\mathrm{CH}_{3} \mathrm{SO}_{3}\right)_{2}$ and $0.1 \mathrm{M} \mathrm{Bi}\left(\mathrm{NO}_{3}\right)_{3}$, $\mathrm{Ce}\left(\mathrm{NO}_{3}\right)_{3}$ as dopants.

X-ray powder diffraction data were collected on a STOE STADI P automatic diffractometer [17] equipped with linear PSD detector (transmission

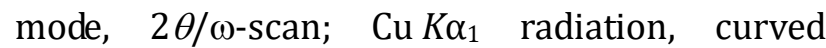
germanium (111) monochromator; $2 \theta$-range $6.000 \leq 2 \theta \leq 102.945^{\circ} 2 \theta$ with step $0.015^{\circ} 2 \theta$; PSD step $0.480^{\circ} 2 \theta$, scan time $50 \mathrm{~s} / \mathrm{step}$ ).

Qualitative and quantitative phase analysis was performed using the PowderCell program [18]. For selected samples with relatively high degree of crystallinity the Rietveld refinement was carried out using FullProf.2k (version 5.40) program [19].

The electrooxidation of organic compounds was carried out in divided cell at $\mathrm{j}_{\mathrm{a}}=50 \mathrm{~mA} \mathrm{~cm}^{-2}$. The volume of anolyte was $1300 \mathrm{~cm}^{3}$. Solution, containing phosphate buffer $\left(0.25 \mathrm{M} \mathrm{Na}_{2} \mathrm{HPO}_{4}+\right.$ $\left.0.1 \mathrm{M} \mathrm{KH}_{2} \mathrm{PO}_{4}\right)+2 \cdot 10^{-4} \mathrm{M}$ organic compound, $(\mathrm{pH}=6.55)$ was used as electrolyte. Stainless steel was used as cathode. Modified lead dioxide electrodes were used as anodes. Electrode surface area was $2.5 \mathrm{~cm}^{2}$.

Analyses of the reaction products were conducted by HPLC using a Shimadzu RF-10A xL instrument equipped with a Ultraviolet SPD-20AV detector and a $30 \mathrm{~cm}$ Discovery ${ }^{\circledR} \mathrm{C} 18$ column. The formation of colored compounds during electrolysis was followed by UV-visible spectroscopy using a UV mini 1240 Shimadzu spectrometer.

The composition and structure of intermediates was confirmed by HPLC using a Shimadzu RF-10A xL instrument equipped with a Ultraviolet SPD-20AV detector and a $30 \mathrm{~cm}$ Discovery ${ }^{\circledR} \mathrm{C} 18$ column.

Since the action of iron(III) chloride to monohydric and polyhydric phenols in aqueous neutral or weakly acidic solutions having the characteristic color, which does not depend, however, on the structure of phenols [20], a qualitative analysis of diluting solution with $1 \%$ solution of iron(III) chloride was conducted.
It is known that salicylic acid gives violet, hydroquinone, 2,3-dihydroxybenzoic and 2,5-dihydroxybenzoic acids give blue color. If in the ortho position to the phenolic groups are complexing group, the color with iron(III) chloride appears both in water and alcohol medium, resulting in formation of complex iron salts. These complexing groups include mainly carbonyl (aldehyde and ketone), carboxyl, hydroxyl and alkoxyl, and sulpho-groups [20].

\section{Results and Discussion}

Since the electrodeposition of lead(IV) oxide occurs through the formation of chemisorbed oxygen-containing particles, the presence in the electrolyte of ionic dopants which can be adsorbed or form oxygen-containing compounds with these particles on the surface of the electrode, leads to changes in kinetic regularities of $\mathrm{PbO}_{2}$ formation and physicochemical properties of coatings. The electrodeposition rate is affected by the composition of the electrolyte.

The typical morphology of lead(IV) oxide that was deposited from nitrate and methanesulfonate electrolytes, is shown on fig. 1. As one can see (fig. 1a), $\mathrm{PbO}_{2}$ obtained from nitrate solutions is represented by a set of large polycrystalline blocks with no significant preferences in crystallographic orientation [15]. The using of methanesulfonate electrolytes leads to significant changes in the morphology of the coating (fig. 1b). In this case, polycrystalline blocks are not formed and the surface is a mixture of randomly oriented fine-grained crystals of nano and submicron size with a uniform surface. Specific electrode surface increases in several times. A similar phenomenon was observed when the polyelectrolyte and surfactant particles were included in the growing $\mathrm{PbO}_{2}$ deposit [21].

In order to determine the influence of deposition conditions and the composition of the anode materials, based on lead dioxide, on their electrocatalytic activity in respect to the oxidation of organic toxicants salicylic acid and its derivatives were selected as model aromatics.

According to [14], quite a number of intermediates are produced during anodic oxidation of salicylic acid. The primary intermediates include dihydroxybenzoic acids.

Electronic absorption spectra of solutions at different electrolysis time were taken in order to determine the time of the disappearance of intermediate aromatic products and a change in the concentration of the initial compound. 


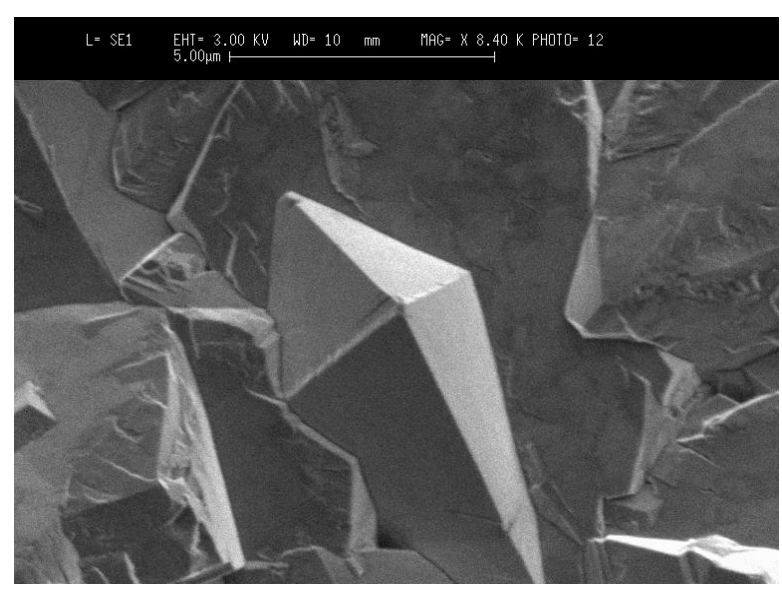

$a$

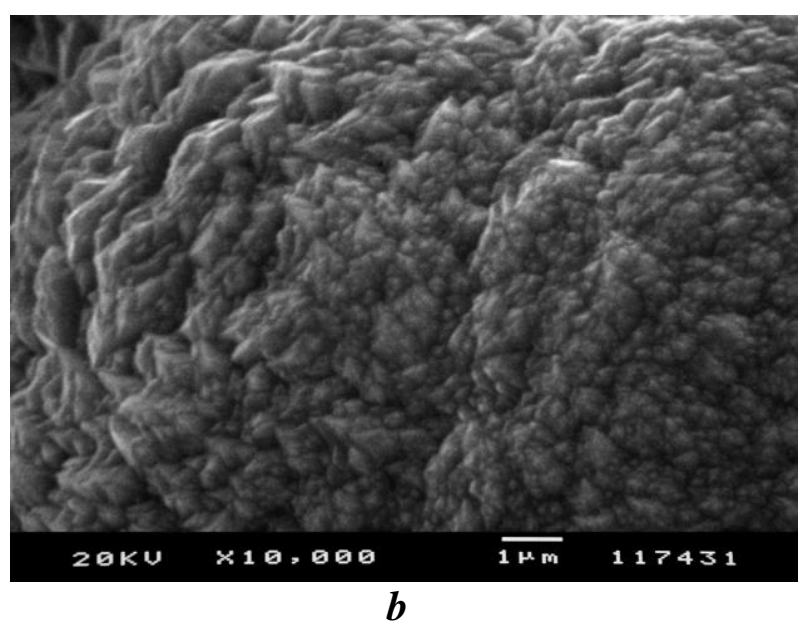

$b$

Fig. 1. SEM micrographs of coatings, obtained from next solutions: $a-0.1 \mathrm{M} \mathrm{Pb}\left(\mathrm{NO}_{3}\right)_{2}+0.1 \mathrm{MHNO}_{3}$; $b-0.1 \mathrm{M} \mathrm{Pb}\left(\mathrm{CH}_{3} \mathrm{SO}_{3}\right)_{2}+0.1 \mathrm{M} \mathrm{CH}_{3} \mathrm{SO}_{3} \mathrm{H}$

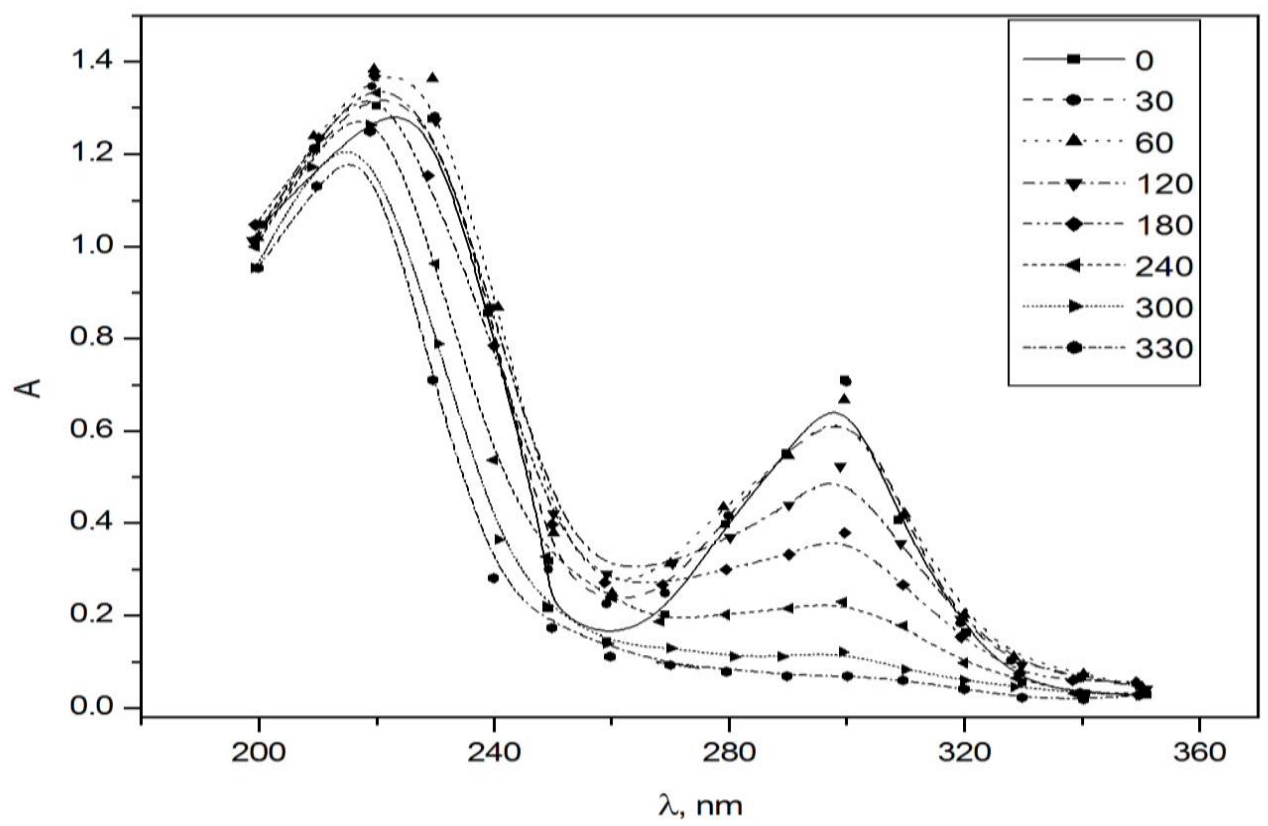

Fig. 2. The absorption spectra of salicylic acid solution (initial concentration $2 \cdot 10^{-4} \mathrm{M}$ ) obtained at different time of electrolysis in a phosphate buffer on lead dioxide anode, $\mathrm{pH}=6.55$

Fig. 2 shows the absorption spectra in the visible and UV regions obtained at different times of electrolysis in a phosphate buffer on nonmodified lead dioxide anode.

The initial solution of salicylic acid is characterized by a peak in the $290-300 \mathrm{~nm}$. After 30 minutes of electrolysis the intensity of the peak decreases and the plateau at $250-270 \mathrm{~nm}$ appears, due to the drop in the concentration of salicylic acid and the formation of intermediate aromatic products. Further increase in electrolysis time leads to the disappearance of peak at $290-300 \mathrm{~nm}$, and reducing the plateau at 250-270 nm due to the complete destruction of salicylic acid and intermediates. After 5.5 hours of electrolysis the complete conversion of aromatic compounds with the formation of only aliphatic products takes place.
Phenolic compounds are known to form intensely colored complex compounds with aqueous solutions of $\mathrm{FeCl}_{3}$. And with the accumulation of hydroxyl groups in the ring, as well as decarboxylation the color of complexes changes from blue to purple then to blue or green [19]. We used this feature of phenol derivatives in order to deal with products that are formed during oxidation. Salicylic acid with $\mathrm{FeCl}_{3}$ forms violet colored complex. After 30 minutes of electrolysis the color of solution changed to blueviolet, indicating a partial destruction of salicylic acid and accumulation of 2,3-, 2,5-dihydroxybenzoic and trihydroxybenzoic acids. They give dark blue color with ferric chloride. After 2 hours the violet color completely disappeared and the solution became intensely blue, that in our opinion, demonstrates the complete destruction 


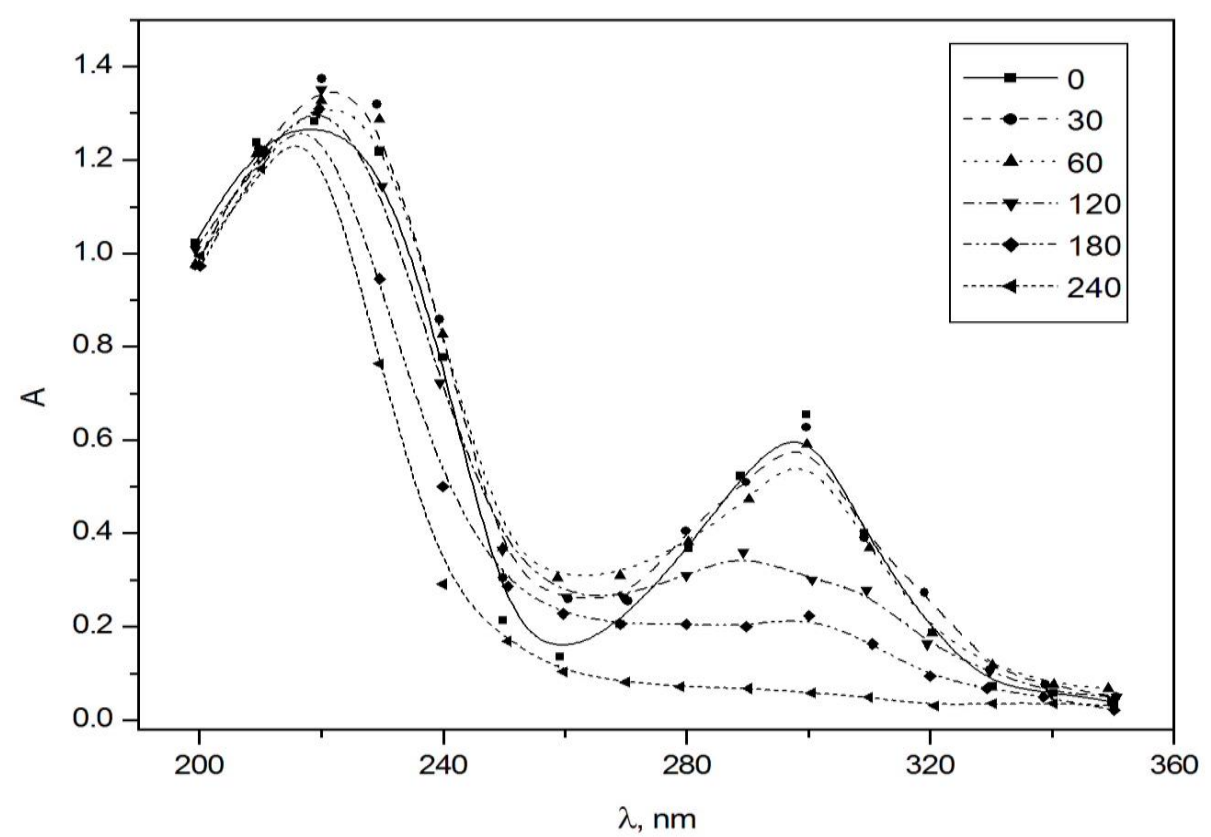

Fig. 3. The absorption spectra of salicylic acid solution (initial concentration $2 \cdot 10^{-4} \mathrm{M}$ ) obtained at different time of electrolysis in a phosphate buffer on $\mathrm{PbO}_{2}-\mathrm{Bi}$ anode, $\mathrm{pH}=6.55$

of salicylic acid and hydroquinone accumulation, which is rapidly oxidized to benzoquinone. Over time, the color of the solution becomes blue, light blue and colorless, indicating the gradual destruction of aromatic products.

The process of oxidation of salicylic acid on lead dioxide anodes, modified by bismuth results in 4 hours, which is 1.5 hours faster compared to nonmodified anodes, as evidenced by electronic absorption spectra (fig. 3). We have not seen the appearance of violet-blue color by using the qualitative reaction. After 30 minutes of electrolysis the solution was blue, after 60 minutes saturated blue, and after 180 minutes the color was almost disappeared.

Table 1 represents the phase composition of lead dioxide. In this case, structural factors play a significant role. Maximum electrocatalytic activity is achieved by increasing the proportion of $\alpha$-phase, on the one hand, and increase the crystalline zone of oxide on the other, which leads to increased amounts of oxygen containing particles strongly bounded to the electrode surface that participate in the electrochemical oxidation of aromatic compounds [22].

Table 1

The phase composition of lead dioxide coatings depending on deposition conditions

\begin{tabular}{lll}
\hline Deposit & $\mathrm{T} / \mathrm{K}$ & $\begin{array}{l}\text { Content } / \mathrm{wt} . \% / \\
\alpha-\mathrm{PbO}_{2} / \beta-\mathrm{PbO}_{2}\end{array}$ \\
\hline $\mathrm{PbO}_{2}$ & 282 & $59 / 41$ \\
$\mathrm{PbO}_{2}$ & 298 & $90 / 10$ \\
$\mathrm{PbO}_{2}-\mathrm{Bi}$ & 282 & $5 / 95$ \\
$\mathrm{PbO}_{2}-\mathrm{Ce}$ & 298 & $83 / 17$ \\
\hline
\end{tabular}

The degradation rate is lower on lead dioxide anodes, modified by cerium ions. The complete destruction of aromatics ended after 5 hours. Qualitative reaction to benzoic acid derivatives showed a similar color shift as in the case of anodes, modified by bismuth.

Obviously, these processes proceed through the same intermediates and qualitatively are not different. But one can see different catalytic activity of modified and nonnmodified lead dioxide anodes.

During the sulfosalicylic acid oxidation we observed no differences in the rate of destruction of the initial compound at various anodes. In all cases, the process ended after 4.5 hours (fig. 4).

Interesting results were obtained during the oxidation of 5-aminosalicylic acid. The presence of amino-group obviously increases the amount of formed intermediates. The gradual color change of the solution confirms the multistage process. It was colorless first, but after 30 minutes it became yellow, after 120 minutes the color was yellowbrown; after 150 minutes the color intensity was reduced to colorless. The absorption spectra also show preliminary oxidation of the amino group.

The initial acid solution is characterized by a peak in the 320-340 nm (fig. 5). After 120 minutes one can see peak shifting in the 290$310 \mathrm{~nm}$ region, indicating the complete destruction of amino-group; the plateau gradually appears in the $260-280 \mathrm{~nm}$, indicating the formation of benzoquinones. Unlike salicylic acid (see fig. 2), the complete conversion of 5-aminosalicylic acid is slightly slower. 
The presence of donor functional group reduces the rate of the 5-aminosalicylic acid oxidation. The process is completed after 6.5 hours on lead dioxide anodes.

On electrodes modified by bismuth the process is much faster - about 4 hours. In our opinion bismuth ions accelerate the transition to benzoquinones due to the ease of oxidation of the amino-group to hydroxy-. It is known that in the phenolic compounds such destruction is always formed benzoquinones, which is hardly degraded. Obviously, the sooner the compound formed less time is needed for the decomposition of the initial compound. On electrodes modified by cerium the process is much slower and results in 5 hours.

As one can see from electronic absorption spectra of 5-aminosalicylic acid, in all cases after 120 minutes the appearance of new compounds in the reaction mixture can be witnessed, as evidenced by the shift of the absorption peak in the region of 290-300 $\mathrm{nm}$. Thus the highest activity in respect to aminosalicylic acid oxidation exhibit lead dioxide anodes modified by bismuth. For other derivatives of salicylic acid difference in time of the destruction on modified and nonmodified lead dioxide anodes was less significant.

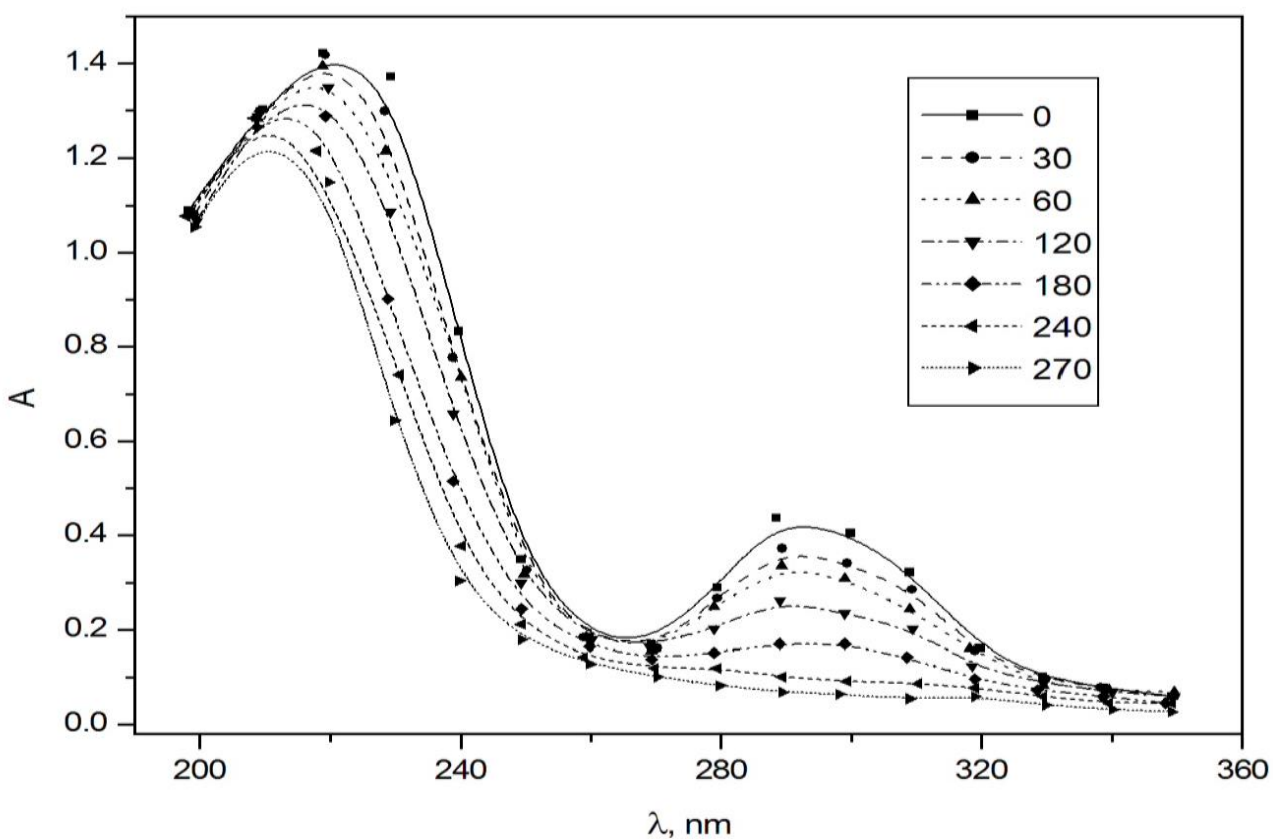

Fig. 4. The absorption spectra of sulfosalicylic acid solution (initial concentration $10^{-4} \mathrm{M}$ ) obtained at different time of electrolysis in a phosphate buffer on lead dioxide anode, $\mathrm{pH}=6.55$

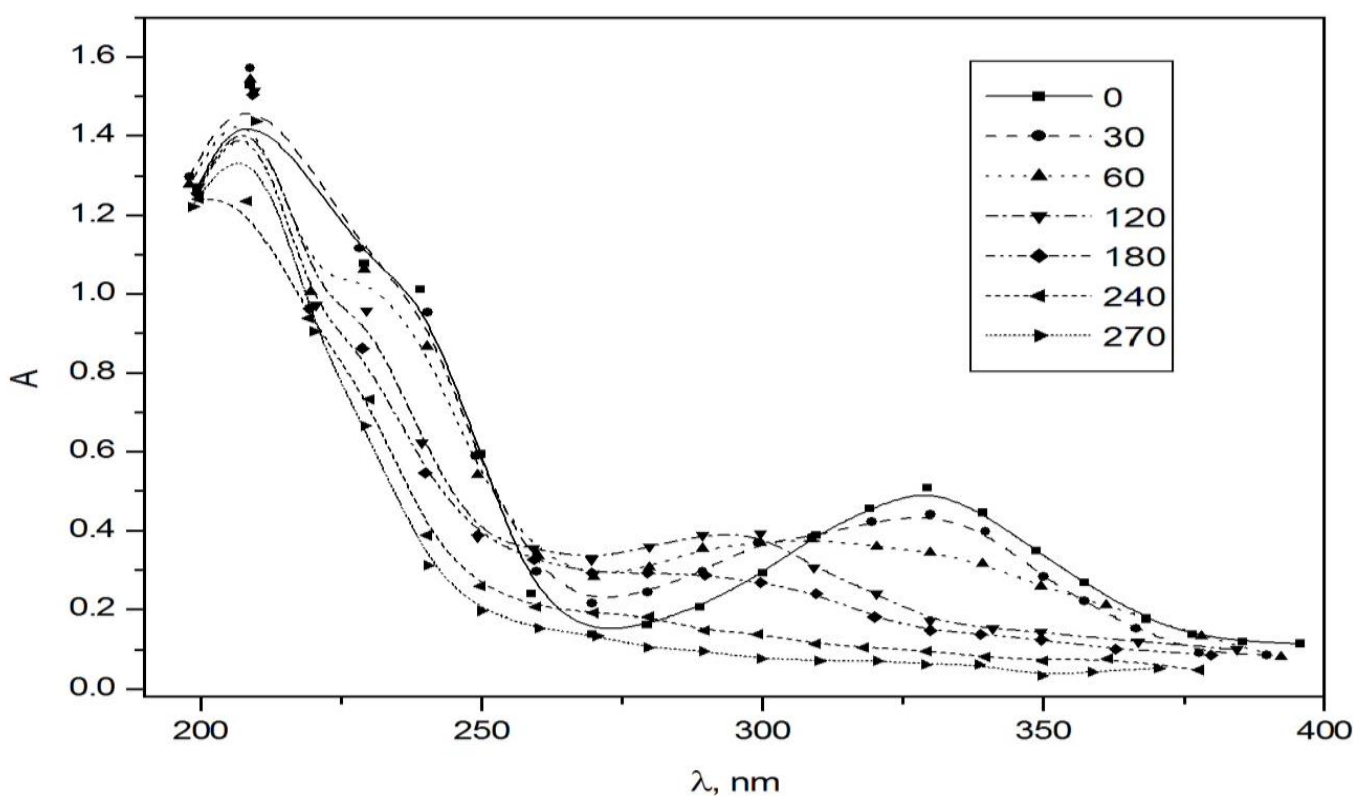

Fig. 5. The absorption spectra of 5 -aminosalicylic acid solution (initial concentration $2 \cdot 10^{-4} \mathrm{M}$ ) obtained at different time of electrolysis in a phosphate buffer on $\mathrm{PbO}_{2}-\mathrm{Bi}$ anode, $\mathrm{pH}=6.55$ 
The processes of electrochemical oxidation of investigated organic compound on unmodified and modified lead dioxide electrodes occur qualitatively the same and differ only in the rate. This suggests the invariability of the mechanism of their oxidation on different materials that allows one for a correct comparison of their electrocatalytic activity.

According to calculations (table 2), based on kinetic studies of the reaction rate constant of salicylic acid degradation depends on the composition of the electrode material and varies due to the nature and content of ionic additives in lead dioxide.

Table 2

Kinetic parameters of the electrochemical oxidation of salicylic acid $\left(2 \cdot 10^{-4} \mathrm{M}\right)$ on modified $\mathrm{PbO}_{2}$-anodes

\begin{tabular}{ll}
\hline Anode & $\begin{array}{l}\text { Apparent heterogeneous rate } \\
\text { constant, } \mathrm{k} \cdot 10^{2}, \mathrm{~min}^{-1}\end{array}$ \\
\hline $\mathrm{PbO}_{2}$ & 0.70 \\
$\mathrm{PbO}_{2}-\mathrm{Bi}$ & 0.81 \\
$\mathrm{PbO}_{2}-\mathrm{Ce}$ & 0.72 \\
\hline
\end{tabular}

The maximum interest for the electrochemical destruction of organic substances represents lead dioxide electrodes modified by bismuth to which a rate constant of salicylic acid oxidation increases in 1.2 times compared with nonmodified electrodes. In other cases, the rate constants are comparable.

Intermediates formed during the oxidation of salicylic and sulfosalicylic acids depend on conditions of the oxidation. Often these intermediates are $\alpha-, \beta$-resorcinol acid, gallic acid, pyrocatechol, hydroquinone [14]. All of these compounds oxidized to benzoquinones, which is further degraded into aliphatic acids - succinic, maleic, oxalic, etc. But the general stage of destruction of salicylic and sulfosalicylic acids are aromatic nucleus hydroxylation and decarboxylation.

Hydroxylation occurs in the $o$ - and $p$-position to the carboxyl group with the formation of isomeric dihydroxybenzoic acids. Decarboxylation of salicylic acid occurs at heating and leads to the formation of phenols.

Further oxidation leads to the formation of diketones and their oxidation through di- and monocarboxylic acid to carbon dioxide (scheme 1).

Stages of sulfosalicylic acid oxidation coincide with salicylic acid oxidation. The multistage of this process confirmed by the colour change of ferrous sulfate aqueous solutions of hydroxy acids during the electrolysis: colorless $\rightarrow$ yellow $\rightarrow$ orange $\rightarrow$ brown $\rightarrow$ colorless, indicating that the reaction occurs through a series of intermediates.

The rate of conversion of organic compounds depends on the nature of organics on the one hand and the nature of the anode material on the other. Experimental data show that there is no universal anode material on which the conversion rate would be maximized. In each case the choice of material was individual.

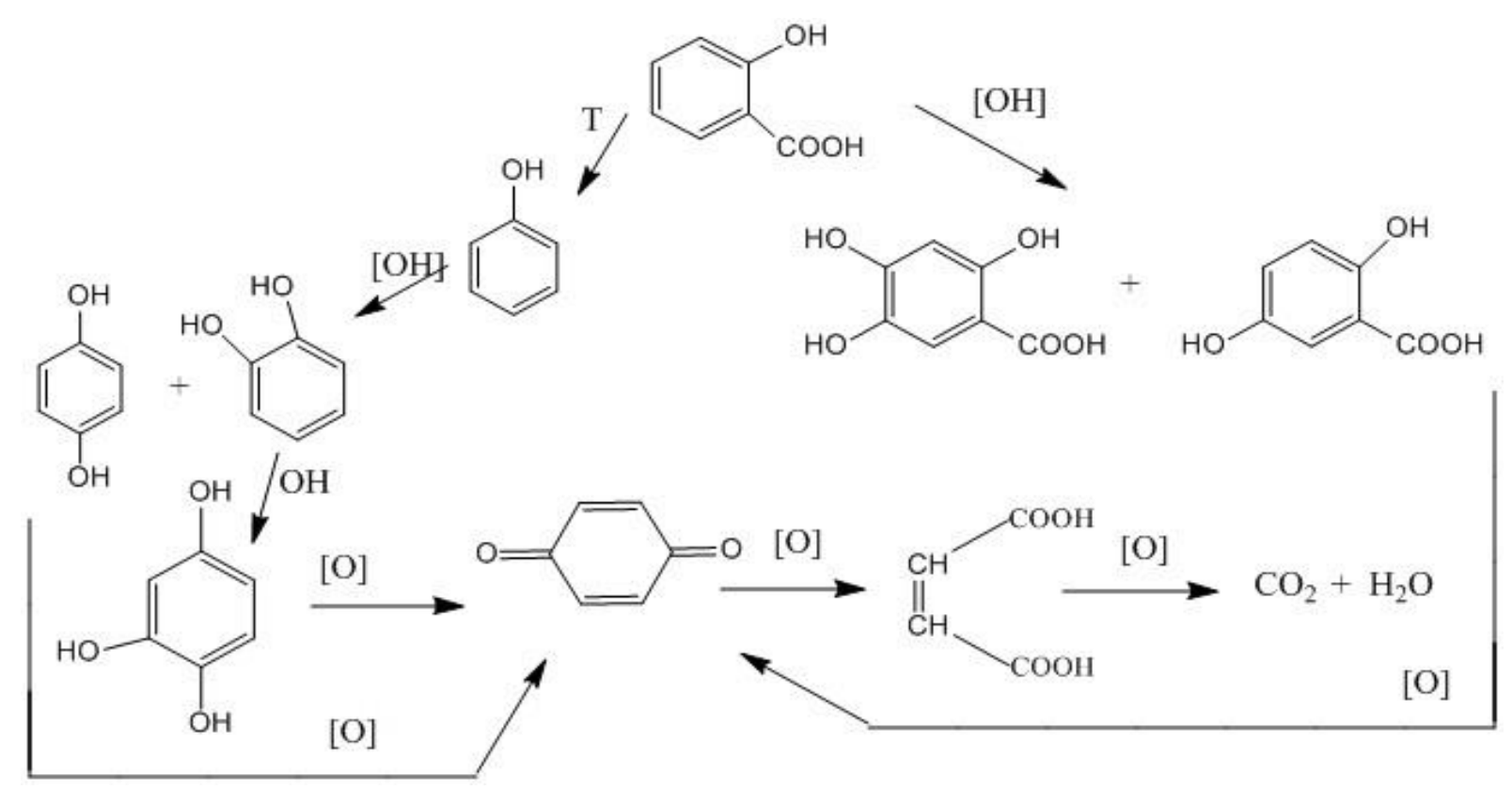

Scheme 1. The oxidation of salicylic acid

\section{Conclusions}

It has been found that the destruction of salicylic acid in the first stage occurs through the accumulation of aromatic hydroxylation products, and during the complete destruction - incineration to form aromatic aliphatic compounds.

It is shown that the use of $\mathrm{PbO}_{2}$, deposited from methanesulfonate electrolytes and modified electrodes significantly reduces the conversion 
time of salicylic acid in aliphatic products compared to lead dioxide anodes obtained by traditional technology from nitrate bath. The highest degradation rate occurs at the anodes modified by bismuth. It was found that the destruction of the 5-aminosalicylic acid occurs through an intermediate oxidation of aminogroup to hydroxy.

\section{Bibliography}

[1] Oturan M. A. Advanced oxidation processes in water/ wastewater treatment: principles and applications. A review / M. A. Oturan, J.-J. Aaron // Crit. Rev. Env. Sci. Tech. - 2014. - Vol. 44. - P. 2577-2641.

[2] Chaplin B. P. Critical review of electrochemical advanced oxidation processes for water treatment applications / B.P. Chaplin // Environ. Sci.: Processes Impacts. - 2014. - Vol. 16. - P. 1182-1203.

[3] Electrochemical oxygen transfer reactions: electrode materials, surface processes, kinetic models, linear free energy correlations, and perspectives. A review / R. Vargas, C. Borras, D. Mendez [et al.] // J. Solid State Electrochem. - 2016. - Vol. 20. - P. 875-893.

[4] Brillas E. Decontamination of wastewaters containing synthetic organic dyes by electrochemical methods. An updated review / E. Brillas, C. A. Martinez-Huitle // Appl. Catal., B. - 2015. - Vol. 166-167. - P. 603-643.

[5] Martinez-Huitle C. A. Decontamination of wastewaters containing synthetic organic dyes by electrochemical methods: A general review / C. A. Martinez-Huitle, E. Brillas// Appl Catal., B. - 2009. - Vol. 87. - P. 105-145.

[6] Reaction sequence for the mineralization of the shortchain carboxylic acids usually formed upon cleavage of aromatics during electrochemical Fenton treatment / M. A. Oturan, M. Pimentel, N. Oturan, I. Sires // Electrochim. Acta. - 2008. - Vol. 54. - P. 173-182.

[7] Degradation of chlorophenols by means of advanced oxidation processes: a general review / M. Pera-Titus, V. Garcla-Molina, M. A. Bacos [et al.] // Appl. Catal., B. 2004. - Vol. 47. - P. 219-256.

[8] Enache T. A. Phenol and para-substituted phenols electrochemical oxidation pathways / T. A. Enache, A. M. Oliveira-Brett // J. Electroanal. Chem. - 2011. Vol. 655. - P. 9-16.

[9] Dhaouadi A. Degradation of paraquat herbicide by electrochemical advanced oxidation methods / A. Dhaouadi, N. Adhoum // J. Electroanal. Chem. 2009. - Vol. 637. - P. 33-42.

[10] A review on advanced oxidation processes for the removal of taste and odor compounds from aqueous media / M. Antonopoulou, E. Evgenidou, D. Lambropoulou, I. Konstantinou // Water Res. - 2014. - Vol. 53. P. 215-234.

[11] Cattarin S. Electrosynthesis of nancomposite materials for electrocatalysis / S. Cattarin, M. Musiani // Electrochim. Acta. - 2007. -Vol. 52. - P. 1339-1348.

[12] Photoelectrochemical oxidation of salicylic acid and salicylaldehyde on titanium dioxide nanotube arrays / M. Tian, B. Adams, J. Wen [et al.] // Electrochim. Acta. 2009. -Vol. 54. - P. 3799-3805.

[13] Study on production of free hydroxyl radical and its reaction with salicylic acid at lead dioxide electrode / S. Ai, Q. Wang, H. Li, L. Jin // J. Electroanal. Chem. 2005. - Vol. 578. - P. 223-229.
[14] Electrogeneration of hydroxyl radicals on boron-doped diamond electrodes / B. Marselli, J. Garcia-Gomez, P.-A. Michaud [et al.] // J. Electrochem. Soc. - 2003. Vol. 150. - P. D79-D83.

[15] Mineralization of salicylic acid in acidic aqueous medium by electrochemical advanced oxidation processes using platinum and boron-doped diamond as anode and cathodically generated hydrogen peroxide / E. Guinea, C. Arias, P. L. Cabot [et al.] // Wat. Res. 2008. - 42. - P. 499-511.

[16] Electrodeposition of $\mathrm{Ni}^{2+}$-doped $\mathrm{PbO}_{2}$ and physicochemical properties of the coating / O. Shmychkova, T. Luk'yanenko, R. Amadelli, A. Velichenko // J. Electroanal. Chem. - 2016. - Vol. 774. - P. 88-94.

[17] STOE WinXPOW, version 3.03. Darmstadt: Stoe \& Cie $\mathrm{GmbH}, 2010$.

[18] Kraus W. PowderCell for Windows (version 2.4) / W. Kraus, G. Nolze. - Berlin: Federal Institute for Materials Research and Testing, 2000.

[19] Rodriguez-Carvajal J. Recent developments of the program FULLPROF, Commission on Powder Diffraction (IUCr) / J. Rodriguez-Carvajal // Newsletter. 2001. - Vol. 26. - P. 12-19.

[20] Shriner R. L. The systematic identification of organic compounds / R. L. Shriner, C. K. F. Hermann, T. C. Morrill [et al.]. - 8th Edition, Hoboken, NJ: John Wiley \& Sons, Inc., 2004. - $736 \mathrm{p}$.

[21] Nafion effect on the lead dioxide electrodeposition kinetics / A. Velichenko, T. Luk'yanenko, N. Nikolenko [et al.] // Russ. J. Electrochem. - 2007. - 43. - P. 118-120.

[22] Electrooxidation of some phenolic compounds at Bidoped $\mathrm{PbO}_{2} / \mathrm{O}$. Shmychkova, T. Luk'yanenko, A. Yakubenko [et al.] // Appl. Catal., B. - 2015. Vol. 162. - P. 346-351.

\section{References}

[1] Oturan, M. A., Aaron, J.-J. (2014). Advanced oxidation processes in water/wastewater treatment: principles and applications. A review. Crit. Rev. Env. Sci. Tech., 44, 2577-2641. doi: http://dx.doi.org/10.1080/10643389.2013.829765

[2] Chaplin, B.P. (2014). Critical review of electrochemical advanced oxidation processes for water treatment applications. Environ. Sci.: Processes Impacts., 16, 1182-1203. doi: http://dx.doi.org/10.1039/C4EM90018A

[3] Vargas, R., Borras, C., Mendez, D., Mostany, J., Scharifker, B. R. (2016). Electrochemical oxygen transfer reactions: electrode materials, surface processes, kinetic models, linear free energy correlations, and perspectives. A review. J. Solid State Electrochem., 20, 875-893. doi: https://doi.org/10.1007/s10008-015-2984-7

[4] Brillas, E., Martinez-Huitle, C. A. (2015). Decontamination of wastewaters containing synthetic organic dyes by electrochemical methods. An updated review. Appl. Catal., $B$, 166-167, 603-643. doi: https://doi.org/10.1016/j.apcatb.2014.11.016

[5] Martinez-Huitle, C. A., Brillas, E. (2009). Decontamination of wastewaters containing synthetic oranic dyes by electrochemical methods: a general review. Appl. Catal., B, 87, 105-145. doi: https://doi.org/10.1016/j.apcatb.2008.09.017

[6] Oturan, M. A., Pimentel, M., Oturan N., Sires, I. (2008). Reaction sequence for the mineralization of the short-chain carboxylic acids usually formed upon cleavage of aromatics during electrochemical fenton treatment. Electrochim. Acta, 54, 173-182. doi: https://doi.org/10.1016/j.electacta.2008.08.012 
[7] Pera-Titus, M. Garcia-Molina, V., Bacos, M. A., Gimenez, J., Esplugas, S. (2011). Degradation of chlorophenols by means of advanced oxidation processes: a general review. Appl. Catal., B, 47, 219256. doi: https://doi.org/10.1016/j.apcatb.2003.09.010

[8] Enache, T. A., Oliveira-Brett, A. M. (2011). Phenol and para-substituted phenols electrochemical oxidation pathways. J. Electroanal. Chem., 655, 9-16. doi: https://doi.org/10.1016/j.jelechem.2011.02.022

[9] Dhaouadi, A., Adhoum, N. (2009). Degradation of paraquat herbicide by electrochemical advanced oxidation methods. J. Electroanal. Chem., 637, 33-42. doi: https://doi.org/10.1016/j.jelechem.2009.09.027

[10] Antonopoulou, M., Evgenidou, E., Lambropoulou, D., Konstantinou, I. (2014). A review on advanced oxidation processes for the removal of taste and odor compounds from aqueous media. Water Res., 53, 215-234. doi: https://doi.org/10.1016/j.watres.2014.01.028

[11] Cattarin, S., Musiani, M. (2007). Electrosynthesis of nancomposite materials for electrocatalysis. Electrochim. Acta, 52, 27962805. doi: https://doi.org/10.1016/j.electacta.2006.07.035

[12] Tian, M., Adams, B., Wen, J., Asmussen, R. M., Chen, A. (2009). Photoelectrochemical oxidation of salicylic acid and salicylaldehyde on titanium dioxide nanotube arrays. Electrochim. Acta, 54, 3799-3805. doi: https://doi.org/10.1016/j.electacta.2009.01.077

[13] Ai, S., Wang Q., Li, H., Jin, L. (2005). Study on production of free hydroxyl radical and its reaction with salicylic acid at lead dioxide electrode. J. Electroanal. Chem., 578, 223-229. doi: https://doi.org/10.1016/j.jelechem.2005.01.002

[14] Marselli, B., Garcia-Gomez, J., Michaud, P.-A., Rodrigo, M. A., Comninellis Ch. (2003). Electrogeneration of hydroxyl radicals on boron-doped diamond electrodes. J. Electrochem. Soc., 150, D79-D83. doi: http://dx.doi.org/10.1149/1.1553790
[15] Guinea, E., Arias, C., Cabot, P. L., Garrido, J. A., Rodriguez, R. M., Centellas, F., Brillas, E. (2008). Mineralization of salicylic acid in acidic aqueous medium by electrochemical advanced oxidation processes using platinum and boron-doped diamond as anode and cathodically generated hydrogen peroxide. Wat. Res., 42, 499-511. doi: https://doi.org/10.1016/j.watres.2007.07.046

[16] Shmychkova, O., Luk'yanenko, T., Amadelli, R., Velichenko, A. (2016). Electrodeposition of $\mathrm{Ni}^{2+}$ doped $\mathrm{PbO}_{2}$ and physicochemical properties of the coating. J. Electroanal. Chem., 774, 88-94. doi: https://doi.org/10.1016/j.jelechem.2016.05.017

[17] STOE WinXPOW, version 3.03. (2010). Darmstadt: Stoe \& $\mathrm{Cie} \mathrm{GmbH}$.

[18] Kraus, W., Nolze, G. (2000). PowderCell for Windows (version 2.4) Berlin: Federal Institute for Materials Research and Testing.

[19] Rodriguez-Carvajal, J. (2001). Recent developments of the program FULLPROF, Commission on Powder Diffraction (IUCr). Newsletter, 26, 12-19.

[20] Shriner, R. L., Hermann, C. K. F., Morrill, T. C., Curtin, D. Y., Fuson, R. C. (2004). The systematic identification of organic compounds. 8th Edition, Hoboken, NJ: John Wiley \& Sons, Inc. doi: https://doi.org/10.1021/np058223w

[21] Velichenko, A., Luk'yanenko, T., Nikolenko, N., Amadelli, R., Danilov, F. (2007). Nafion effect on the lead dioxide electrodeposition kinetics. Russ. J. Electrochem., 43, 118-120. doi: https://doi.org/10.1134/S102319350701017X

[22] Shmychkova, O., Luk'yanenko, T., Yakubenko, A., Amadelli, R. Velichenko, A. (2015). Electrooxidation of some phenolic compounds at Bi-doped $\mathrm{PbO}_{2}$. Appl. Catal, B, 162, 346-351. doi: https://doi.org/10.1016/j.apcatb.2014.07.011 